\title{
Enhancing Students' English Language Skills through Active Learning at an Islamic University
}

\author{
Rio Febriannur Rachman \\ Universitas Airlangga \\ rio.febriannur.rachman-2018@fisip.unair.ac.id
}

\section{Article History}

Received: 02 November 2021

Reviewed: 17 November 2021

Accepted: 28 November 2021

Published: 13 December 2021

Keywords: active learning, case study, Islamic university

\begin{abstract}
English is the most widely used international language in the world. Mastering English skills in this modern era is, therefore, crucial. Consequently, English needs to be sufficiently taught to students of all educational levels. In response to the issue, this study aims to investigate the active learning strategy (intense involvement of students in learning processes) employed in the Faculty of Islamic Da'wah and Communication at an Islamic Institute in Lumajang, East Java. This study was designed as a case study with in-depth interviews and observations as the main data collection. The results of this study indicate that although the active learning method was successfully implemented in this faculty, the strategies and learning activities should be varied.
\end{abstract}

\section{INTRODUCTION}

The ability to speak English in the modern era is quite important. English is the most popular international language in the world. Therefore, educational institutions at the elementary, middle, and higher levels, seek to formulate strategies for improving English language skills for students. As a means of global communication, English needs to be actively mastered both orally and in writing (Siming et al., 2021).

In this globalization era, information exchange is carried out through the internet. On social media, a lot of information and knowledge source is conveyed in English. Therefore, students need to have proficiency in mastering English. English proficiency is not only a requirement for students to study abroad but also to explore the science that is more global in nature. The updated knowledge and information contained in international journals are generally available in English. The problem is that students are constrained in mastering English as a mandatory skill that must be possessed at this time (Thariq et al., 2021).

It is interesting to study strategies to improve English skills on Islamic campuses because, in a number of cases, some of the students are already proficient in using foreign languages. However, the Arabic language is also used. The reason is that many Islamic 
campuses, especially those based on Islamic boarding schools, have students who are Islamic-based high school graduates. Improving students' English skills is often associated with a number of theories regarding skills training. One of them is the theory of active learning, which explains education oriented to the participation of teachers or lecturers and students. All higher education stakeholders need to adapt the condition of the students, then use appropriate learning methods, including the method of learning English.

This article discusses learning English at the Faculty of Islamic Da'wah and Communication at an Islamic Institute in Lumajang. In this faculty, eighty percent of the students come from Islamic-based secondary schools or Islamic boarding schools. The theoretical basis for this study is the active learning model, and the case study was employed. This study is expected to add the body of knowledge of active learning models and the phenomenon of learning English on Islamic campuses.

\section{LITERATURE REVIEW}

\section{Active Learning}

One of the popular learning models in the current era is active learning. Active learning has its own characteristics. There are five characteristics of the active learning model. First, the learning process focuses on activities other than listening to the instructions that focus on developing skills. Second, students are directed to do critical thinking. Third, students must be actively involved in all processes, not just listening. Fourth, students are also educated in aspects of attitudes and values. Fifth, there is feedback in the learning process (Bonwell \& Eison, 1991).

The Active Learning model can be stated as a compatible learning model for many subjects, so it is recommended to be implemented, especially at the higher education level (Lewis \& Harrison, 2012). In the post-modern era, where the participants come from the millennial generation and are indicated as critical individuals, this model is considered as one of the good alternatives. As a consequence, lecturers need to have the ability to formulate active learning formulas that are in accordance with student conditions (Roman, 2014). It is also important to note that the success of this learning model does not only depend on the students but also on the lecturers and the institutions. 


\section{Previous Research}

This study uses several previous studies as a reference. One of them is an article entitled Metode Pembelajaran Bahasa Inggris Tingkat SMP di Nuraida Islamic Boarding School Bogor (English language learning method for Nuraida Islamic Boarding School Bogor). The research describes the urgency of learning English in Islamic-based schools. The result of this research is the existence of a learning model using the jigsaw method, descriptive text assignment method, and demonstration method (Zulkarnindra, 2021). The difference between that research and this study lies in the method and theoretical basis.

Another research that is used as a reference is entitled Pondok Pesantren Nurul Hidayah Bantan dalam Meningkatkan Speaking Performance Santri (Improving students' speaking performance at Pondok Pesantren Nurul Hidayah Bantan). There are two types of English learning activities at the Nurul Hidayah Islamic Boarding School (henceforth Pondok), namely activities in the classroom and outside the classroom. Activities in the classroom are determined and limited according to the KMI Gontor curriculum. While activities outside the classroom include Daily English Conversations, English Video Screenings, English Speech Practices, Competitions, and English Games. The advantage of this learning activity is that the Pondok already has a system and method of learning English that is quite good and effective in training students' English skills. Awareness and interest of students to speak English have grown. The language environment has been built. The weakness is that the number of personnel in language affairs is still inadequate compared to the total number of students (Kamaliasari \& Amrizal, 2021). The difference between that research and this study lies in the method and theoretical basis. In addition, that research only saw one aspect of English skills, speaking.

Another research that is used as a reference in this study is entitled Pendampingan Pembelajaran Bahasa Inggris Dasar Pada Santri Pondok Pesantren Nurul Huda Sukaraja (Mentoring program of English for elementary students at Santri Pondok Pesantren Nurul Huda Sukaraja). The research describes the English language learning strategies of the students in Islamic boarding schools. This activity was carried out for four and a half months by providing basic English materials, including grammar, vocabulary, and conversation. This activity received a good response from the students (Warohma et al., 2021). The research which is also used as a reference is entitled Implementasi Pembelajaran English-Speaking pada Pondok Pesantren Tradisional Al Mustaqim: Tantangan untuk Dakwah Global (The implementation of English-speaking program at Pondok Pesantren Tradisional Al Mustaqim: 
A challenge of global da'wah). The research describes the urgency of a breakthrough regarding English learning in Islamic institutions (Rosyada \& Ramadhianti, 2021).

\section{METHODOLOGY}

\section{Research Design}

This study uses a qualitative method with a case study approach. Qualitative studies describe phenomena comprehensively (Bogdan \& Taylor, 1990). Qualitative research places humans as instruments, prioritizes the process rather than the results, also limits it to certain criteria for the validity of the data, and is continuously adapted to field conditions. Case studies examine events, situations using systematic ways of observing, collecting data, and reporting the results (Yin, 2003). The phenomenon seen in this study is the Faculty of Da'wah and Islamic Communication strategy in an Islamic Institute in Lumajang to enhance students' English ability. While the case or challenge faced is the fact that most of the students are graduates of Islamic high schools. The Islamic high school where they studied provide international language lessons or conduct classes more in Arabic than English.

\section{Data Collection}

Data were collected by observing the classes for twenty days in September, except on holidays. Deep interviews were also conducted with a number of sources: the dean, the Head of the Da'wah Management study program, the Head of the Islamic Communication and Broadcasting study program, and the Head of the Islamic Guidance and Counseling study program. Three students from the three study programs were also interviewed, one student from each class. They are graduates of Islamic high schools.

\section{Data Analysis}

Data analysis in this study was carried out in several stages. First, data reduction obtained from observations, interviews, and document/literature studies was concluded through the researcher's interpretation. Second, data presentation was collected and described in the form of categories to facilitate the verification process. At this stage, a synopsis and qualitative data collection were obtained. Third, conclusions were drawn continuously throughout the research by observing the data and the theory used. 


\section{FINDINGS}

There is an English course in the first semester for all students in the faculty. This compulsory course ensures that English language skills are essential in life in this modern era. "The campus language center provides students with a standard curriculum" (The Dean of Faculty of Da'wah and Islamic Communication, Zainil Ghulam, interviewed on September $\left.2^{\text {nd }}, 2021\right)$. Some references used at the Da'wah Management study program are written in English. Meanwhile, courses on theory are given from semester one to semester six. At least once a year, the study program holds an international seminar involving all students (The Head of the Da'wah Management study program, Ahmad Hafiz Lubis, interviewed on September $\left.4^{\text {th }}, 2021\right)$.

The theories and methods used in the Islamic Guidance and Counseling study program refer to many experts from Europe, America, and Arab. There is a lot of literature that has not been translated into Indonesian. Thus, students are forced to read scripts in both English and Arabic until the final semester or thesis work (the Head of the Islamic Guidance and Counseling study program, Bambang Subahri, interviewed on September $\left.5^{\text {th }}, 2021\right)$. In many courses, students are asked to review books in English. The lecturers often use English terms, then translate them to students. Such steps are expected to increase students' knowledge of English (the Head of the Islamic Communication and Broadcasting study program, Ahmad Arifulin Nuha, interviewed on September $\left.13^{\text {th }}, 2021\right)$.

It is believed that English lectures in the first semester can increase students' English language skills. All aspects are trained, such as writing, reading, listening, and conversation. The exams were held strictly. However, the lecturers from the campus language center are communicative (the student of the Da'wah Management study program, Faizah interviewed on September $\left.14^{\text {th }}, 2021\right)$. Attending International seminars and events can increase students' knowledge of English because English is used in all activities. In addition, learning references used in the field of da'wah and Islamic communication are written in either English or Arabic. On the one hand, students feel that this is a challenge. On the other hand, this fact clearly helps students to practice foreign languages. However, the aspects that are trained are only reading and grammar (the student of the Islamic Counseling study program, Izzatul Fardah, interviewed on September $15^{\text {th }}, 2021$ ).

All this time, lecturers have tried to provide an explanation of the terms in the theory and methods used in lectures. However, there are still many students who do not immediately understand. Therefore, students must actively find out for themselves in books or YouTube 
videos (the student of the Islamic Communication and Broadcasting study program, Rizanul Hasan, interviewed on September $23^{\text {rd }}, 2021$ ).

\section{DISCUSSION}

There are various methods of learning English, such as the jigsaw technique to increase listening skills (Alfaruqy, 2021) and nonverbal interaction to strengthen memorization (Isnani, 2021). The other one is Active Learning, which generally develops students' motor skills and critical thinking skills regarding honing the ability. An important element of a learning method is intensity. Teachers must have a holistic agenda that has been measured or calculated, with a target: improving students' English skills. Consistency in the application of teaching methods is a must (Munthe, 2015).

Learning English in the first semester, for students of the Faculty of Da'wah and Islamic Communication in an Islamic Institute in Lumajang, has some certain target such as students can speak English at least for basic conversation. Along with that, students can also listen and understand people who speak English. The fundamental issue is that students can understand some references or literature in English, especially the textbooks and journals. Thus, they are required to attend an English class once a week during a semester. The language skills which are taught are speaking, listening, writing, and also reading. There is a test at the end of each semester. The student must get at least "enough" point to pass the lecture. It would be better if they get a "Special" or "Good" point. Students who cannot pass the class because the point is "Less", must re-take the course next semester (The Dean Faculty of Da'wah and Islamic Communication, Zainil Ghulam, interviewed on September $\left.2^{\text {nd }}, 2021\right)$.

During this time, the number of those who pass is always more than those who do not. For example, in the 2019 batch, out of 13 students, only four failed to get the minimum passing grade (the student of the Islamic Communication and Broadcasting study program, Rizanul Hasan, interviewed on September 23 ${ }^{\text {rd }}$, 2021). Punishment needs to be given in the form of course re-taking to ensure that the students understand the lesson and their motivation sustain (Alsa et al., 2021).

English is indirectly used in all lectures, such as when lecturers explain theories and methods related to the studied disciplines. Many of the theories and methods are from sources or literature which is written in English. During classes, the lecturers mention many English terms. Sometimes, the lecturer explains the meaning of the terms conveyed. On 
another occasion, students take notes on these terms and look up their meanings in dictionaries or other literature (the student of the Islamic Guidance and Counseling study program, Izzatul Fardah, interviewed on September $\left.15^{\text {th }}, 2021\right)$.

This kind of learning model is in line with the active learning method, particularly regarding students' seriousness to study on their own. They look for the meaning of the terms actively. In the classroom, both offline and online, lecturers and students are always faced with time constraints. Therefore, students are required to be active to optimize their learning potential, especially when learning English. Meanwhile, lecturers must also be able to direct the students they teach appropriately. When communicating with students, lecturers sometimes mix the languages of Indonesian and English. This strategy can help students to learn English. The implementation of mixed language learning methods can make learning more effective and efficient (Rahman \& Ismaya, 2021).

Some lecturers give assignments for students in the form of writing books and journal reviews written in English. The literature that the students read is in English. Meanwhile, they review in Indonesian. Thus, they carry out at least two steps of learning processes. First, when they are reading, there is an attempt to translate English sentences into Indonesian. The translation process occurs both in the brain and through reading a dictionary or complementary applications such as Google Translate. Second, they process what they read in the brain by summarizing and explaining the meaning. Through this way, there is a validation of creativity in students (the Head of the Islamic Communication and Broadcasting study program, Ahmad Arifulin Nuha, interviewed on September $13^{\text {th }}, 2021$ ).

Doing a book or journal review written in English has many benefits, such as train students to understand the contents and practice their English skills. In the review process, one learns grammar and translation. The brain is sharpened to be creative and innovative when translating the contents of the book both in mind and in notes. In addition, choosing the appropriate diction when writing the review results is also a beneficial practice for students (Bailey \& Christian, 2021).

Active learning can be done with all the facilities, including the use of internet-based social media (Effendi, 2013). Several experts classify social media based on models of how to use it (Kaplan \& Haenlein, 2012). The first model is collaborative social media, a website that allows users to change the content or informative information, such as Wikipedia. The second type is blogs and/or microblogs, where users express opinions, especially through text, such as Twitter. Third, the social media type allows users to 
download and upload content whose content can also be accessed by other users. The form of content varies, such as video, audio, a compilation of text and images. An example of social media like this is YouTube. Fourth, a network that is broader than blogs and microblogs that have links to certain groups. An example of social media like this is Facebook. Fifth, the virtual game world or Virtual Game World is also popular as online games. This game can be played together between people who have a certain avatar or profile. Sixth, the virtual social world or Virtual Social World which is similar to Virtual Game World, but this social media offers a new life in cyberspace. Users can interact with other people who want to live in cyberspace, with logic and conditions like in the real world. One of the social media platforms that carries this concept is Second Life.

Every individual, armed with a laptop or smartphone, can become a social media user. Using the platforms that one wants, interaction and messaging can be practiced. A person can greet, talk, and even ridicule each other on the same platform, without age restrictions, social backgrounds, and other barriers that are difficult to penetrate if they are in the real world. People can also release their blogs to share tips related to their hobbies to tweet idealistic statements in a matter or two about global issues. The geographical dividing wall has fallen, and the interaction pattern has undergone an accelerating revolution in recent decades. The great power in the sphere of collaboration, participation, empowerment, and time efficiency makes social media popular with the public (Bertot \& Jaeger, 2010).

Social media helps civilizations grow and develop. Although it has always been a double-edged sword, it is believed to be a supporter of all kinds of human affairs, including the economic, political, cultural, social, and other spheres of life. It is also a catalyst for people to be more creative and innovative to provide added value in their daily lives (Geyskens et al., 2002).

In the Faculty of Islamic Da'wah and Communication, some lecturers have used social media as a means of supporting learning. The lecturers ask students to listen to content on social media, be it from the website, Facebook, YouTube, and others. After that, the students comment on the content, and some of the content are shared by English-speaking lecturers. However, there are only a few forms of Indonesian language content. At least, students can learn English from the shared English content (the Head of the Islamic Guidance and Counseling study program, Bambang Subahri, interviewed on September $5^{\text {th }}, 2021$ ). 


\section{CONCLUSION}

Active learning was implemented for students of the Faculty of Islamic Da'wah and Communication in the first semester. The strategy of the lecturers to introduce English references is in accordance with some of the characteristics of the active learning method. Those are reading activities and critical thinking. However, there is no feedback and developing values, and the students cannot be involved in all learning English processes. The task of reviewing or reading English textbooks is only under some of the characteristics of the active learning method, such as reading activities and critical thinking, and making feedback. Not all of them were involved in the process, and their skills were not developing. The faculty has made efforts to enhance students' English skills. However, those strategies still need to be developed in order to make the results better. The use of social media content as a means of learning English needs to be optimized. Moreover, social media has become part of the information source in the current era. In fact, the use of social media has not been carried out by all lecturers optimally, and the content shared is not yet English-oriented.

\section{LIMITATIONS AND STUDY FORWARD}

This study has limitations, including the limited time for data collection. Thus, the data presented in this study is less optimal. However, this study can serve as an overview of the challenges faced by Islamic campuses in efforts to enhance students' English skills. Further studies can be based on this research by using questionnaires distributed to lecturers and students. The goal is to formulate the right method for learning English on Islamic campuses.

\section{REFERENCES}

Alfaruqy, D. (2021). The implementation of the jigsaw technique to increase students' listening achievement and motivation aspects. ELE Reviews: English Language Education Reviews, 1(1), 22-40.

Alsa, A., Hidayatullah, A. P., \& Hardianti, A. (2021). Strategi belajar kognitif sebagai mediator peran motivasi belajar terhadap prestasi belajar. Gadjah Mada Journal of Psychology (GamaJoP), 7(1), 99-114.

Bailey, K. M., \& Christian, D. (2021). Research on teaching and learning English in underresourced contexts. Routledge.

Bertot, John C, Paul T. Jaeger, J. M. G. (2010). Using ICT to create a culture of transparancy: e-government and social media as openness and anticorruption tools for societies. Government Information Quarterly, 27(3), 264-271. 
Bogdan, R., \& Taylor, S. J. (1990). Looking at the bright side: a positive approach to qualitative policy and evaluation research. Qualitative Sosiology, 13(2), 183-192.

Bonwell, C. C., \& Eison, J. A. (1991). Active learning: creating excitement in the classroom. 1991 ASHE-ERIC Higher Education Reports. ERIC Clearinghouse on Higher Education.

Effendi, M. (2013). Integrasi pembelajaran active learning dan internet-based learning dalam meningkatkan keaktifan dan kreativitas belajar. Nadwa: Jurnal Pendidikan Islam, 7(2), 283-308.

Geyskens, I., Gielens, K., \& Dekimpe, M. G. (2002). The market valuation of internet channel additions. Journal of Marketing, 66(2), 102-119.

Isnani, N. (2021). The influence of English teacher's nonverbal interaction on EFL students' perception of learning. ELE Reviews: English Language Education Reviews, 1(1), 121.

Kamaliasari, S., \& Amrizal. (2021). Aktifitas pembelajaran bahasa Inggris di pondok pesantren Nurul Hidayah Bantan dalam meningkatkan speaking performance santri. Akademika: Jurnal Keagamaan Dan Pendidikan, 17(1), 14-30.

Kaplan, A. M., \& Haenlein, M. (2012). Social media: back to the roots and back to the future. Journal of Systems and Information Technology, 14(2), 101-104.

Lewis, S., \& Harrison, M. (2012). Online delivery as a course adjunct promotes active learning and student success. Teaching of Psychology, 39(1), 72-76. https://doi.org/10.1177/0098628311430641

Munthe, A. P. (2015). Pentingnya evaluasi program di institusi pendidikan: sebuah pengantar, pengertian, tujuan dan manfaat. Scholaria: Jurnal Pendidikan Dan Kebudayaan, 5(2), $1-14$.

Rahman, M., \& Ismaya. (2021). Blended learning method to optimize English language learning in non-English language education departments at Muhammadiyah University of Enrekang. Majesty Journal, 3(1), 8-14.

Roman, A. (2014). Methods of designing integrated learning. Journal Plus Education, 11(2), 31-36.

Rosyada, A., \& Ramadhianti, A. (2021). Implementasi pembelajaran English-speaking pada pondok pesantren tradisional Al Mustaqim: tantangan untuk dakwah global. E-Dimas: Jurnal Pengabdian Kepada Masyarakat, 12(3), 428-437.

Siming, M. S. M., Liwang, N. S., Kusumawardhani, R., Dikastuti, N. A., Zulkifli, \& Syamsidah, S. (2021). Pentingnya bahasa Inggris untuk anak usia dini di kelurahan Mangasa. Journal Lepa-Lepa Open, 1(1), 30-33. 
Thariq, P. A., Husna, A., Aulia, E., Djusfi, A. R., Lestari, R., Fahrimal, Y., \& Jhoanda, R. (2021). Sosialisasi pentingnya menguasai bahasa Inggris bagi mahasiswa. Jurnal Pengabdian Masyarakat: Darma Bakti Teuku Umar, 2(2), 316-325.

Warohma, E., Abdillah, M. I., \& Arini, S. M. (2021). Pendampingan pembelajaran bahasa Inggris dasar pada santri pondok pesantren Nurul Huda (PPNH) Sukaraja. Manhaj: Jurnal Penelitian Dan Pengabdian Masyarakat, 10(1), 81-89.

Yin, R. K. (2003). Case study research. Sage Publications Ltd.

Zulkarnindra, E. (2021). Metode pembelajaran bahasa Inggris tingkat SMP di Nuraida islamic boarding school Bogor. Rayah Al-Islam, 5(2), 437-446. 